\title{
CREDIT RISK MANAGEMENT PRACTICES AND PERFORMANCE OF NIGERIA BANKS
}

\author{
${ }^{1}$ LUCKY EJIEH. UJUJU, ${ }^{2}$ JULIUS OVUEFEYEN EDORE \\ 1,2DEPARTMENT OF BANKING/FINANCE, \\ DELTA STATE POLYTECHNIC, OZORO, DELTA STATE
}

DOI: 10.46609/IJSSER.2020.v05i05.010 URL:https://doi.org/10.46609/IJSSER.2020.v05i05.010

\begin{abstract}
The study investigates risk management, risk concentration and performance of Nigeria banks. The variables of credit to private sector, liquidity ratio, nonperforming loan and loan and advances were regressed in return on asset (ROA). Unit root and Ordinary Least Square (OLS) regression analysis were used to test the variables in the study. The study revealed that credit to private sector, liquidity ratio and loan and advances has positive and significant effect in return on asset (ROA) while nonperforming loan has negative and insignificant effect in return on asset (ROA). The study thus concludes that risk management has positive effect on the performance of commercial banks in Nigeria and support Moody`s KMV portfolio manager model which is a credit monitor model that helps to solve the lending problems of banks and further look at the repayment incentive problems. Among the recommendations is that banks Management should establish sound lending policies, adequate credit administration procedure and an effective and efficient machinery to monitor lending function with established guidelines, reduction of interest rates on lending. Financial institutions should all together, set up credit bureau system which is a form of data bank where every bank will submit the names of its defaulting customers for references by others. This will equally frustrate multiple borrowing from banks for the same purpose by the dubious customers.
\end{abstract}

Keywords: Liquidity ratio, non performing loan, credit, risk.

\section{SECTION ONE}

\section{INTRODUCTION}

\subsection{Background to the Study}




\section{International Journal of Social Science and Economic Research}

ISSN: $2455-8834$

Volume: 05, Issue: 05 "May 2020"

Banks are germane to economic development through the financial services they provide. Their intermediation role can be said to be a catalyst for economic growth. The efficient and effective performance of the banking industry over time is an index of financial stability in any nation. The extent to which a bank extends their operation to the public for productive activities accelerates the pace of a nation's economic growth and its long-term sustainability (Kolapo, Ayeni \& Oke, 2012). In the 21st century business environment is added multifaceted and intricate than ever. The majority of businesses have to trade with uncertainties and qualms in every dimension of their operations. Without a doubt, in the present-day's unpredictable and explosive atmosphere all the banks are in front of a hefty risks like: credit risk, liquidity risk, operational risk, market risk, foreign exchange risk, and interest rate risk, along with others risks, which may possibly intimidate the survival and success of the bank's Corporate Performance. The Nigerian banking industry has been strained by the deteriorating quality of its risk related assets as a result of the significant dip in equity market indices, global oil prices and sudden depreciation of the naira against global currencies (BGL Banking Report, 2010). The poor quality of the banks' loan assets hindered banks to extend more credit to the domestic economy, thereby adversely affecting economic performance. This prompted the Federal Government of Nigeria through the instrumentality of an Act of the National Assembly to establish the Asset Management Corporation of Nigeria (AMCON) in July, 2010 to provide a lasting solution to the recurring problems of non-performing loans that bedeviled Nigerian banks (Kolapo, et al, 2012).

In the last few years, Nigerian banking industry suffered an historic retrogressive trend in both profitability and capitalization. Just 3 out of 24 banks declared profit, 8 banks were said to be in 'grave' situation due to capital inadequacy and risk asset depletion; the capital market slummed by about 70 percent and most banks had to recapitalize to meet the regulatory directive $(\mathrm{CBN}$, 2010). This drama in the banking sector eroded public confidence in banking and depositors funds aggregately dropped by $41 \%$ in the period. Possibly due to financial liberalization and globalization, the fact is there has been a reckless abandonment of the essentials of managing risk in times of economic boom and recession; the volatility of bank earnings has been underrated by bank managements. The central monetary authorities also impacted negatively on stability of the sector. The auditing exercise was a very good one but the sanctity and policy implementation mode was bad considering the nature of the Nigerian economy. Basically, bank objectives revolve around 3 directions: profitability, growth in asset and customer base. Aremu, Suberu, \& Oke (2010) pointed out that the major problem of bank management is the misprioritization of short term goals over its long term objectives. While the profitability centres on the quality of short term reprievable assets and liabilities, net worth expansion which is the equity capital, is a function of total asset and liability. In Nigeria, it has been observed that most bank managers have focused more on profitability (which usually is a short term objective), with little attention on risk managing the quality of assets which has better impact on the long term 


\section{International Journal of Social Science and Economic Research}

ISSN: $2455-8834$

Volume: 05, Issue: 05 "May 2020"

sustainability of a financial institution. The risks that are faced by businesses can be categorized into financial and non-financial risks. Both of these types of risks are very vital in order to safely run any business. Sadaqat, Akhtar, \& Ali, (2011) also scrutinizes credit risk having its financial nature and operational risk with its non-financial nature in context to Nigerian Commercial Banks, as financial market of Nigeria is among volatile markets of the world which is filled with anonymity and escapade performances.

\subsection{Statement of the Problem}

The Nigerian Commercial Banking industry has experienced series of problems right from the early 30s down to the middle of the first decade of the new millennium. In 1930 for instance, 21 banks failed. In 1958 when the Central Bank of Nigeria was founded, about 9 banks failed. Still in 1989, about 7 banks failed. In 2006, the numbers of banks were reduced to 24 from 87 . As if it is not enough, the number continued to fluctuate from 25 to 24 and so on. The most recent record of banks failure in Nigeria was 2011 when 3 banks were acquired by the Asset Management Corporation of Nigeria (AMCON). Perhaps this problem is subject to recurrence. The question is: does it mean that these banks are not managing their risks at all; or is it that they are managing them poorly?

It is bewildering indeed when one begins to examine the Nigerian scenario of the financial crises; it is incomparable and sometimes very strange! Another question that comes to mind is why it is difficult for these Banks to find a lasting solution to this seeming customary problem in the industry. The study therefore attempts to assess the risk management strategies obtainable in the commercial Banks in Nigeria. The consequences of bank failures are numerous and very unpalatable, not only to the depositors but also the investors, the general banking public and indeed, the entire economy. The regulators and operators have also not had it easy when financial institutions collapse. Bank failures, in general, impair financial intermediation and efficient allocation of resources. They retard individual well-being and economic progress.

\subsection{Objective of the Study}

The main objective of the study is to investigate risk management, risk concentration and performance of Nigeria banks: the specific objectives are to:

1. examine the effect of credit to private sector on return on asset

2. Determine the effect of liquidity ratio on return on asset.

3. Evaluate the effect of nonperforming loan on return on asset.

4. Assesses the effect of loan and advances on return on asset.

\subsection{Research Questions}




\section{International Journal of Social Science and Economic Research}

ISSN: $2455-8834$

Volume: 05, Issue: 05 "May 2020"

The following research questions were formulated to guide the direction of this research work.

1. To what extent does credit to private sector affect return on asset?

2. To what extent does liquidity ratio affect return on asset?

3. To what degree does nonperforming loan affect return on asset?

4. To what extent does loan and advances affect return on asset?

\subsection{Research Hypotheses}

The following hypotheses are formulated to guide the study:

$\mathrm{Ho}_{1}$ : credit to private sector does not exert significant effect on return on asset.

$\mathrm{Ho}_{2}$ : liquidity ratio does not exert significant effect on return on asset.

Ho3: Nonperforming loan does not exert significant effect on return on asset

Ho4: Loan and advances does not exert significant effect 0 n return on asset

\subsection{Significance of the Study}

Policy Makers: The study will aid policy and monetary authorities, as they would be able to establish the effect of the monetary policy on the commercial banks in Nigerian and hence understand their role in attainment of desired economic growth for the country.

Stakeholders in the Banking Sector: The study would also be of importance to various stakeholders in the banking sector among them bank's customers who are keen to know why the cost of borrowing has suddenly increased in the recent past. Understanding the effect of bad on cost of borrowing would help the consumers to make borrowing decisions.

Nigeria Government: The study would also benefit the government as it would provide an insight to the effect of bad debt on loan and credit management on the commercial banks in Nigeria. The government partners with banks to ensure price, interest rates and liquidity ratio stability and enhance economic development through provision of affordable credit.

Academics: academics, including students of finance, banking and other related fields will find the study useful for further studies the results of this study would also be valuable to researchers and scholars, as it would form a basis for further research. Besides this study would contribute to the pool of knowledge into the relationship between bad debt, loan and credit management in commercial banks in Nigeria and therefore contribute to academic reference materials.

\subsection{Scope of the Study}


International Journal of Social Science and Economic Research

ISSN: $2455-8834$

Volume: 05, Issue: 05 "May 2020"

This study will cover the effect of risk management in Nigeria banks using time series data from 1986 to 2016 . The explanatory variables to be considered in the study are credit to private sector, liquidity ratio, nonperforming loan and loan and advances and the dependent variable is return on asset

1.8 Limitations of the Study The researcher was constrained by some factors. However, the researcher was able to overcome those factors in other to achieve this study. Those factors include; the availability of data, modification of the available models, improvement in the existing literature and the expansion of the scope to 2016. Amongst other issues which the researcher were able to overcome in other to achieve this study.

\section{SECTION TWO}

\section{REVIEW OF RELATED LITERATURE}

\subsection{Conceptual frame work}

\subsection{Risk}

Risk is part of life. Avoiding all risk would result in no achievement, no progress and of course, no reward. Ordinarily, risk is associated with the likelihood of a negative outcome. However, in management, risk is the chance that an investment's actual return will be different than expected. A fundamental idea in finance is the relationship between risk and return on investment. It implies future uncertainty about deviation from expected earnings or expected outcome and measures the uncertainty that an investor is willing to take to realize a gain from an investment. There are different types of risks: liquidity risk, sovereign risk, insurance risk, business risk, default risk and so on (The Economic Times, 2015).

From the above, it could be noted that there are different definitions of risk for each of several applications. The widely inconsistent and ambiguous use of the word is one of several current criticisms of the methods to manage risk (Douglas, 2009). The ISO 31000 (2009) /ISO Guide 73 definition of risk is the 'effect of uncertainty on objectives'. In this definition, uncertainties include events (which may or not happen) and uncertainties caused by a lack of information or ambiguity. This definition also includes both negative and positive impacts on objectives. The ISO 31000:2009 covers information security management measurements, generally known as security metrics.

\subsubsection{Risk Management}

Risk management is a systematic process of understanding, evaluating and addressing risks to maximize the chances of objectives being achieved and ensuring organizations, individuals and 


\section{International Journal of Social Science and Economic Research}

ISSN: $2455-8834$

Volume: 05, Issue: 05 "May 2020"

communities are sustainable. It also enables the organization to be aware of new possibilities. In effect, risk management requires an informed understanding of relevant risks, an assessment of their relative priority and a rigorous approach to monitoring and controlling them. It is indeed the practice of identifying potential risks in advance, analyzing them and taking precautionary steps to reduce or curb the risk. In finance and business term, when an organization makes an investment decision, it exposes itself to a number of financial risks. The quantum of such risks depends on the type of financial instrument. The financial risks might be in form of high inflation, volatility in capital markets, recession and bankruptcy and so on. In order to minimize and control the exposure of investment to such risks, bank managers and investors resort to the practice of 'risk management'. Tsevisani (2007) holds the view that the interaction between human factors and tangible aspects of risk highlights the need to focus closely on human factors as one of the main drivers for risk management: a change driver that comes first of all from the need to know how humans perform in changing environments and in the face of risks.

\subsubsection{Risk Management Strategies}

Risk management strategies are measures employed by banks to avoid or minimize the adverse effect of risk. This includes the identification, analysis, assessment, control and avoidance, minimization or elimination of unacceptable risks. As a strategy, an organization may use risk assumption, risk avoidance, risk retention, risk transfer or any other strategy (or combination of strategies) in effective management of future events. Therefore a sound risk management framework is crucial for commercial banks to enhance their profitability and guarantee survival. The key principles in credit risk management process are sequenced as follows: establishment of a clear structure, allocation of responsibility, prioritized processes, discipline and responsibilities should be clearly communicated and accountability assigned. Specifically, the strategies for hedging risk include but not limited to:

\section{Risk Derivatives}

This provides banks with an approach which does not require them to adjust their loan portfolio. Credit derivatives provide banks with a new source of fee income and offer banks the opportunity toreduce their regulatory capital (Shao \& Yeager, 2007). The commonest type of credit derivative is credit default swap whereby a seller agrees to shift the credit risk of a loan to the protection buyer. Recent innovations in credit derivatives markets have improved lenders' abilities to transfer credit risk to other institutions while maintaining relationship with borrowers (Marsh, 2008).

\section{Credit Securitization}


International Journal of Social Science and Economic Research

ISSN: $2455-8834$

Volume: 05, Issue: 05 "May 2020"

It is the transfer of credit risk to a factor or insurance firm and this relieves the bank from monitoring the borrower and fear of the hazardous effect of classified assets. This approach insures the lending activity of banks. The growing popularity of credit risk securitization can be put down to the fact that banks typically use the instrument of securitization to diversify concentrated credit risk exposures and to explore an alternative source of funding by realizing regulatory arbitrage and liquidity improvements when selling securitization transactions (Michalak \& Uhde,2009). A cash collateralized loan obligation is a form of securitization in which assets (bank loans) are removed from a bank's balance sheet and packaged (tranched) into marketable securities that are sold on to investors via a special purpose vehicle (SPV) (Marsh,2008).

\section{Compliance to Basel Accord}

The Basel Accord is international principles and regulations guiding the operations of banks to ensure soundness and stability. The Accord was introduced in 1988 in Switzerland. Compliance with the Accord means being able to identify, generate, track and report on risk-related data in an integrated manner, with full audit ability and transparency and creates the opportunity to improve the risk management processes of banks. The New Basel Capital Accord places explicitly the onus on banks to adopt sound internal credit risk management practices to assess their capital adequacy requirements (Chen and Pan, 2012).

\section{Adoption of a Sound Internal Lending Policy}

The lending policy guides banks in disbursing loans to customers. Strict adherence to the lending policy is by far the cheapest and easiest method of credit risk management. The lending policy should be in line with the overall bank strategy and the factors considered in designing a lending policy should include; the existing credit policy, industry norms, general economic conditions of the country and the prevailing economic climate (Kithinji,2010).

\section{Credit Bureau}

This is an institution which compiles information and sells this information to banks as regards the lending profile of a borrower. The bureau awards credit score called statistical odd to the borrower which makes it easy for banks to make instantaneous lending decision. Example of a credit bureau is the Credit Risk Management System (CRMS) of the Central Bank of Nigeria $(\mathrm{CBN})$.

\section{Profitability Performance}




\section{International Journal of Social Science and Economic Research}

ISSN: $2455-8834$

Volume: 05, Issue: 05 "May 2020"

The most common measure of bank performance is profitability. Profitability is measured using the following criteria: Return on Assets $(\mathrm{ROA})=$ a net profit/total asset shows the ability of management to acquire deposits at a reasonable cost and invest them in profitable investments (Ahmed, 2009). This ratio indicates how much net income is generated per $£$ of assets. The higher the ROA, the more the profitable the bank is. Return on Equity (ROE) = net profit/ total equity. ROE is the most important indicator of a bank's profitability and growth potential. It is the rate of return to shareholders or the percentage return on each $£$ of equity invested in the bank. Cost to Income Ratio $(\mathrm{C} / \mathrm{I})=$ total cost /total income measures the income generated per $\mathrm{N}$ cost. That is how expensive it is for the bank to produce a unit of output: the lower the C/I ratio, the better the performance of the bank.

\section{Liquidity Performance}

Liquidity indicates the ability of the bank to meet its financial obligations in a timely and effective manner. Samad (2004:36) states that "liquidity is the life and blood of a commercial bank'. Financial liabilities are attracted through retail and wholesale distribution channels. Retail generated funding is considered less interest elastic and more reliable than deposits attracted from wholesale distribution channels (Thygerson, 1995). The following ratios are used to measure liquidity:

Liquid Assets to Deposit-borrowing ratio $($ LADST) $=$ liquid asset/customer deposit and short term borrowed funds. This ratio indicates the percentage of short term obligations that could be met with the bank's liquid assets in the case of sudden withdrawals.

Net Loans to Total Asset ratio $($ NLTA) $=$ Net Loans/Total Assets NLTA measures the percentage of assets that is tied up in loans. The higher the ratio, the less liquid the bank is. Net Loans to Deposit and borrowing $($ NLDST) $=$ Net loans/total deposits and short term borrowings. This ratio indicates the percentage of the total deposits locked into non-liquid assets. A high figure denotes lower liquidity.

\section{Asset Credit Quality (Credit Performance)}

While it is expected that banks would bear some bad loans and losses in their lending activities, one of the key objectives of the bank is to minimize such losses (Casu, Molyneux, \& Girardone, 2006). Credit performance evaluates the risks associated with the bank's asset portfolio i.e. the quality of loans issued by the bank. Several ratios can be used for measuring credit quality however, not all information on the loans is always available. Non-performing loans is not available for all banks therefore this paper use the following ratio: Loan loss reserve to gross loans $(\mathrm{LRGL})=$ Loan loss reserve/gross loans. This ratio indicates the proportion of the total portfolio that has been set aside but not charged off. It is a reserve for losses expressed as a 


\section{International Journal of Social Science and Economic Research}

ISSN: $2455-8834$

Volume: 05, Issue: 05 "May 2020"

percentage of total loans. Ratio Working Capital to Total Asset measures the net liquid assets (i.e. current assets less current liabilities) of a company to its total capitalization. Ratio Retained Earning to Total Assets measures the cumulative profitability over time of a company. Infant company would show an adverse RA/TA ratio because it has no cumulative profits overtime. Ratio Earnings before Interest and Tax to Total Assets measures the true productivity of the company's assets. It is a very significant ratio for studies involving business failure. Ratio of Market Value of Equity to Total Liabilities shows how much the firm's equity can reduce in value before the liabilities exceed the assets and the company becomes insolvent. Equity involves the combination of market value of preference and common shares. Ratio Gross Earning to Total Assets measures the firm's assets utilization. This ratio measures the management capacity in dealing with competitive conditions.

\section{Credit to Private Sector}

World Bank (2009) asserted that private sector credit is the most comprehensive indicator of the activities of the deposit money banks and it is calculated as the amount of domestic credit allocated to the private sector by the banking sector divided by GDP. It indicates the extent to which the banking sector finance the economy and more specifically the extent to which banks finance private investments and private sector development.

Therefore this ratio not only indicates banking system size but also importance of banking system to the private sector of an economy. According to World Bank domestic credit provided to the private Sector includes financial resources which establish a claim for repayment such as loans, purchased of non equity securities, trade credits and other accounts receivables hence this domestic credit excludes credit extended to government and public enterprises (Beck and Levine, 2004). It is expected to have a positive impact on economic growth. This measure of banking sector is critical to poverty reduction and for financing consumption, production and capital formation which helps to stimulates aggregate demand and in turn advance economic activities (World Bank, 2008). Becks, Levin, Loayza(2008) affirmed that this proxy is superior to other measures of financial intermediaries development because it excludes credit to public sector and better reflect the extent of efficient resources allocation.

\section{Liquidity Ratio}

Bank liquidity simply means the ability of the bank to maintain sufficient funds to pay for its maturing obligations. It is the banks' ability to immediately meet cash, cheques, and other withdrawal obligations and legitimate new loan demand while abiding by existing reserve requirements. 


\section{International Journal of Social Science and Economic Research}

ISSN: $2455-8834$

Volume: 05, Issue: 05 "May 2020"

According to Olagunji, (2011), liquidity refers to the ability of a bank to ensure the availability of funds to meet financial commitments or maturing obligations at a reasonable price at all times. Put differently, bank liquidity means banks having money when they need it particularly to satisfy the withdrawal needs of their customers. The survival of deposit money banks depends greatly on how liquid they are, since illiquidity, being a sign of imminent distress, can easily erode the confidence of the public in the banking system and results to run on deposit.

Liquid assets should be marketable or transferable. This means, they are expected to be converted to cash easily and promptly, and are redeemable prior to maturity. Another quality of liquid assets is price stability. Based on this characteristic, bank deposits and short term securities are more liquid than equity investments due to the fact that the prices of the former are fixed than the prices and value of the later (Richard, 2013)

Liquidity is a financial term that means the amount of capital that is available for investment. Today, most of this capital is credit, not cash. Bank Liquidity simply means the ability of the bank to maintain sufficient funds to pay for its maturing obligations. It is the bank's ability to immediately meet cash, cheques, other withdrawals obligations and legitimate new loan demand while abiding by existing reserve requirements. Nwaezeaku (2008) defined liquidity as the degree of convertibility to cash or the ease with which any asset can be converted to cash (sold at a fair market price).

Liquidity management therefore involves the strategic supply or withdrawal from the market or circulation the amount of liquidity consistent with a desired level of short-term reserve money without distorting the profit making ability and operations of the bank. It relies on the daily assessment of the liquidity conditions in the banking system, so as to determine its liquidity needs and thus the volume of liquidity to allot or withdraw from the market. The liquidity needs of the banking system are usually defined by the sum of reserve requirements imposed on banks by a monetary authority (CBN 2012).

Liquidity management therefore is the strategic supply or withdrawal from the market circulation the amount of liquidity Consistent with desired level of short-term reserve money without distorting the profit making ability and operations of the bank (Aghada and Osuji, 2013). Generally, the adequacy of liquidity plays very crucial roles in the successful functioning of all business firms. The ability to meet short-term obligations may affect the firm's operations. Every investor has interest in the liquidity position of the company. However, the issue of liquidity though important to other businesses, is most paramount to banking institutions and this explains why bank show-case cash and other liquid securities in their balance sheet statement. Thus bank ensures that sufficient provision of cash and other near cash securities are made available to meet withdrawals obligation and new loan demand by customers in need of liquidity (Aghada and 


\section{International Journal of Social Science and Economic Research}

ISSN: $2455-8834$

Volume: 05, Issue: 05 "May 2020"

Osuji, 2013). Hence, banks in Nigeria are statutorily required to comply with cash reserve requirement (CRR) policy of the Central Bank of Nigeria as a measure of effectively managing the liquidity position of banks.

\section{Liquidity Management}

Finance in a banking system is liken to the blood in the human system, adequate circulation of this blood in the body means the human system will function well resulting into good health. And the inadequacy will also mean that human system will be weak. Similarly, business can only operate under the state of adequate liquidity. A company is said to be liquid, if it can convert its asset to cash with minimum amount of delay and inconvenience. The optimum capital structure is determined by keeping in mind the long-term and short-term requirements of finance. This is in line with (Biety, 1998), who define liquidity as "the speed and ease with which an asset is sold and still realizes fair price". Therefore liquidity is seen as the inflows and outflows of cash through the firm as product acquisition, sales payment and collection processes taking place over time, with which asset can be converted into cash without a significant loss of principal liquid asset. It is a relationship between the fine dimension (how long it will take to sell) and the price dimension (The discount from fair market price) of an investment asset. Hence, a firm should ensure it does not suffer from lack of liquidity and does not also have excess liquidity. Failure to meet obligation due to lack of sufficient liquidity results in poor credit worthiness and loss of creditors' confidence. However, a high degree of liquidity results in idle cash. Thus, liquidity management as a concept encompasses efficient and effective planning and organization of Bank's assets which will enhance its liquidity and profitability at a minimum cost possible.

\section{Financial Performance of Commercial Banks}

Profit is the ultimate goal of commercial banks. To measure the profitability of commercial banks there are variety of ratios used of which Return on Asset (ROA), Return on Equity (ROE) and Net Interest Margin (NIM) are the major ones, Murthy and Sree (2003).ROE is a financial ratio that refers to how much profit a company earned compared to the total amount of shareholder equity invested or found on the balance sheet.ROE is what the shareholders look in return for their investment.ROA is a ratio of Income to its total asset (Khrawish, 2011). It measures the ability of the bank management to generate income by utilizing company assets at their disposal.

NIM is a measure of the difference between the interest income generated by banks and the amount of interest paid out to their lenders (for example, deposits), relative to the amount of their (interest earning) assets. It is usually expressed as a percentage of what the financial institution earns on loans in a specific time period and other assets minus the interest paid on borrowed 


\section{International Journal of Social Science and Economic Research}

ISSN: $2455-8834$

Volume: 05, Issue: 05 "May 2020"

funds divided by the average amount of the assets on which it earned income in that time period (the average earning assets). The NIM variable is defined as the net interest income divided by total earnings assets (Gulet al, 2011).Equity investors are concerned with the firm's ability to generate, maintain, and increase income. Profitability can be measured in many differing but interrelated dimensions. First there is the relationship of a farm's profits to revenue, that is, the residual return on the firm per sales dollar. Another measure, return on investment (ROI), relates profits to the investment required to generate them. Analysis of income is of vital concern to stock holders because they derive revenue in the form of dividends. Further, increased profits can cause an increase in market price, leading to capital gains (Nimer, 2013).

\subsubsection{Capital Adequacy}

Capital adequacy is a measure of a bank's financial strength, in terms of its ability to withstand operational and abnormal losses. Further considering the regulatory requirement on the minimum capital required to be maintained by banks, capital adequacy also indicates the ability of bank to undertake additional business. The size of capital provides financial flexibility for bank and financial institution. Banks with high capital ratio tend to earn more profit through translating the safety advantage into profit (Ayele, 2012).Capital adequacy ratios how the internal strength of the bank to withstand losses during crisis. Capital adequacy ratio is directly proportional to the resilience of the bank to crisis situations. It has also a direct effect on the profitability of banks by determining its expansion to risky but profitable ventures or areas, Ongore and Kusa (2013).

\subsubsection{Asset Quality}

More often than not the loan of a bank is the major asset that generates the major share of the banks income. Loan is the major asset of commercial banks from which they generate income. The quality of loan portfolio determines the profitability of banks. The loan portfolio quality has a direct bearing on bank profitability. The highest risk facing a bank is the losses derived from delinquent loans (Dang, 2011).The ratio Loan Loss Reserves to Net Interest Revenue (LOSRNI) is a measure of bank's asset quality that indicates how much of the total portfolio has been provided for but not charged off. The higher the ratio the poorer the quality and therefore the higher the risk of the loan portfolio will be (Li, 2007).

\subsubsection{Management Efficiency}

Management Efficiency is one of the key internal factors that determine the bank profitability. It is represented by different financial ratios like total asset growth, loan growth rate and earnings growth rate. Yet, it is one of the complexes subject to capture with financial ratios. Moreover, operational efficiency in managing the operating expenses is another dimension for management quality. The performance of management is often expressed qualitatively through subjective 


\section{International Journal of Social Science and Economic Research}

ISSN: $2455-8834$

Volume: 05, Issue: 05 "May 2020"

evaluation of management systems, organizational discipline, control systems, quality of staff, and others. Yet, some financial ratios of the financial statements act as a proxy for management efficiency. The capability of the management to deploy its resources efficiently, income maximization, reducing operating costs can be measured by financial ratios, Ongoreand Kusa (2013).

\section{Non Performing Loans}

A Non-performing loan is a loan that is in default or close to being in default. Many loans become non-performing after being in default for 90 days, but this can depend on the contract terms. A loan is nonperforming when payments of interest and principal are past due by 90 days or more, or at least 90 days of interest payments have been capitalized, refinanced or delayed by agreement, or payments are less than 90 days overdue, but there are other good reasons to doubt that payments will be made in full (International Monetary Fund, 2012).

In the contemporary banking business, increasing Non-performing loans (NPLs) is a very critical but frequent issue in bank fund management. The situation of NPLs is not only a challenge worldwide but also in Kenya in Kenya .The situation of rising NPLs can damage the confidence of investors and might act as a contagious for financial malaise as it may drive away deserving loan borrowers out of the financial system. The problem of rising Non-performing loans may be attributed to inadequate or weak monitoring \& controls and supervision on the part of banks, weaknesses of legal infrastructure, lack of effective lenders' recourse and poor debt recovery strategies (Adhikary, 2006). Currently, there is no universally accepted definition of NPLs at the practical level. NPLs may be described as portion of bank financial assets from which the bank is no longer receiving interest and/or instalment payments as initially agreed. Choudhury, (2002) explains that NPLs is a multi-class concept since NPLs can be categorised into different categories based on the duration NPL has been overdue. NPLs results from the weaknesses in the administration and supervision of the financial system of which commercial banks are a part of. Study by Bonin and Huang (2001) hold that that the probability of crises in banking industry worsens if financial risks are not eliminated as soon as possible. The crises are known not only to degrade the standard of living but also can water down a number of the previous achievements of economic reform in a short time. Mwangi (2012) argues that there is an inverse relationship between banks financial performance and NPLs. Mwangi (2012) further explains that the greater the value of NPLs the lesser will the financial performance be as proxied by return on asset (ROA) and vice versa.

Non Performing Assets 
International Journal of Social Science and Economic Research

ISSN: $2455-8834$

Volume: 05, Issue: 05 "May 2020"

A Non-performing asset (NPA) is defined as a credit facility in respect of which the interest and/or installment of principal has remained ,past due e for a specified period of time. NPA is a classification used by financial institutions that refer to loans that are in jeopardy of default. Once the borrower has failed to make interest or principle payments for 90 days the loan is considered to be a non-performing asset. Non-performing assets are problematic for financial institutions since they depend on interest payments for income. Troublesome pressure from the economy can lead to a sharp increase in non-performing loans and often results in massive writedowns (International Monetary Fund, 2012).

\subsection{Theoretical Framework}

\section{Moody`s KMV Portfolio Manager Model}

This paper will be anchored upon the Moody`s KMV Portfolio Manager Model

KMV Model is a credit monitor model that helps to solve the lending problems of banks and further look at the repayment incentive problem (Gilbert, 2004). To try resolving the problems, the KMV Model uses the structural relationship between the volatility of a firm's asset and the volatility of the firm's equity. The KMV Corporation (purchased by Moody's in 2002) has turned this relatively simple idea into a credit-monitoring model now used by most of the large US banks to determine the Expected Default Frequency (EDF) that is the probability of default of large corporations (KMV Corporation, 1994).

The expected default frequency that is calculated reflects the probability that the market value of the firm's assets will fall below the promised repayments on debt liabilities in one year. If the value of a firm's assets falls below its debt liabilities, it can be viewed as being economically insolvent. Simulations by the KMV have shown that this model outperforms both accountingbased models and S\&P ratings (Saunders and Cornett, 2007). The relevant net worth of a firm is therefore the market value of the firm's assets minus the firm's default point.

\subsubsection{Theoretical Literature}

\section{Commercial Loan Theory}

The oldest theory of banking is the commercial loan theory, also called the real bills doctrine. The commercial loan theory holds that banks should lend only on short term, self-liquidating, commercial paper.

According to Hosna \& Manzura, (2009), the commercial loan theory is geared to influence persuasively both the bank lending and the general economic activities. Strict adoption of this theory will reveal that it is expected to serve as a monetary supply to changes in aggregate 


\section{International Journal of Social Science and Economic Research}

ISSN: $2455-8834$

Volume: 05, Issue: 05 "May 2020"

economic activity. The popularity of this doctrine among Deposit-Money Banks (DMBs) in Nigeria is evident. Nigerian bankers believe that since their resources were repayable at short notice, such depositors' monies should be employed accordingly in short-term loans. Kargi, (2011) posited that the strong tie to this conception is rather orthodox if consideration is given to the fact that at the time of the supremacy of the theory, there were little or no secondary reserve assets, which could have served as a liquidity buffer for the bank. Moreso, this theory fails to consider the credit needs of Nigeria's developing economy. It has not encouraged banks to fund the purchases of plants, equipment, land, and home-ownership. For a theory to maintain that all loans should be liquidated in the normal course of business shows its failure to recognize the relative stability of bank deposits. Whereas, demand deposits are on demand, all depositors are not likely to demand payment at the same time. Thus, stability of deposits enables a bank to extend funds for a reasonable long period without danger of illiquidity. Though, with its flaws, the commercial loan theory, or real bills doctrine has been a persistent theory of banking. Vestiges of it still remain in the structure of bank regulatory agencies, bank examination procedures and the thinking of many bankers. One cannot understand contemporary banking without an understanding of our banking history, and cannot understand banking history without an understanding of the commercial loan theory.

\section{The Credit Risk Theory}

Credit risk according to Anderson and Salas, \& Saurina, (2002) refers to the risk that a borrower will default on any type of debt by failing to make required payments. The risk is primarily that of the lender and includes lost principal and interest, disrupt loss may be complete or partial and can arise in a number of circumstances, such as an insolvent bank unable to return funds to a depositor. To reduce the lenders risk, the lender may perform a credit check on the prospective borrower, may require the borrower to take appropriate insurance, such as mortgage insurance or seek security or guarantees of third parties. In general, the higher the risk, the higher will be the interest rate that the debtors will be asked to pay on the debt (Owojori, Akintoye \& Adidu, (2011).

\subsubsection{Value at a Risk Theory}

This is a technique used to estimate the probability of portfolio losses based on the statistical analysis of historical price trends and volatilities. Value at risk is commonly used by banks, security firms and companies that are involved in trading energy and other commodities. VAR is able to measure risk while it happens and is an important consideration when firms make trading or hedging decision (Manganelli and Engle, 2001). Value at risk (VAR or sometimes VaR) has been called the "new science of risk management", but you do not need to be a scientist to use VAR. Here, we look at the idea behind VAR and the three basic methods of calculating it. 
Basically, VAR is represented by; Value at risk = Mean *HPR+ [Z-score*STD Dev*SQRT (HPR)] Where mean is the average expected (or actual) rate of return, HPR is the holding period, Z-score is the probability, STD Dev is the standard deviation and SQRT is the square root (of time). For financial institutions, risk is about the odds of losing money given out as loans, a VAR is based on that common-sense fact. By assuming financial institutions care about the odds of a really big loss on loans, VAR answers the question, "What is my worst case scenario?"

\subsection{Empirical Review}

There are various empirical studies that have been conducted to investigate risk management, risk concentration and performance of Nigeria banks

However this study would review those empirical studies, variable by variable using the objectives of the study

\section{Credit to Private Sector and Return on Asset}

Kargi (2011) evaluated the impact of risk management on the profitability of Nigerian banks. The findings revealed that risk management has a significant impact on the profitability of Nigerian banks.

Epure and Lafuente (2012) examined bank performance in the presence of risk management for Costa-Rican banking industry during 1998-2007. The results showed that performance improvements follow regulatory changes and that risk explains differences in banks and nonperforming loans negatively affect efficiency and return on assets while the capital adequacy ratio has a positive impact on the net interest margin.

Kithinji (2010) assessed the effect of credit risk management on the profitability of commercial banks in Kenya. Data on the amount of credit, level of non-performing loans and profits were collected for the period 2004 to 2008. The findings revealed that the bulk of the profits of commercial banks are not influenced by the amount of credit and non-performing loans, therefore suggesting that other variables other than credit and non-performing loans impact on profits. Chen and Pan (2012) examined the risk management efficiency of 34 Taiwanese commercial banks over the period 2005-2008. The results indicated that only one bank is efficient in all types of efficiencies over the evaluated periods.

\section{Liquidity ratio and Return on Asset}

Al-Khouri (2011) assessed the impact of bank's specific risk characteristics, and the overall banking liquidity on the performance of 43 commercial banks operating in 6 of the Gulf Cooperation Council (GCC) countries over the period 1998-2008. The results showed that credit 


\section{International Journal of Social Science and Economic Research}

ISSN: $2455-8834$

Volume: 05, Issue: 05 "May 2020"

risk, liquidity ratio and capital risk are the major factors that affect bank performance when profitability is measured by return on assets

\section{Nonperforming loan and Return on Asset}

Agu and Basil (2013) examine the causes of risk management in Nigeria commercial banks. The result of the study indicates that incessant increase in capital risk is a strong and statistically important factor that causes bad debt in Nigeria commercial banks.

Taiwo and Abayomi (2013) evaluates the impact of risk management on bank profitability of some selected commercial banks in Nigeria. The results from Panel Least Square (PLS) estimate found that the risk management has a significant impact on the profitability of Nigeria banks.

Alice and Jaya (2016) determine the effect of risk management on the financial performance of commercial banks in Rwanda. The study found that client appraisal; credit risk control and collection policy had effect on financial performance of Equity bank.

Talata (2011) examined the effect of non-performing loans on the financial performance. The finding showed that NPLs, loan recovered, cost-income ratio, and total revenue were statistically significant at one percent (1\%) level of significance respectively. however liquidity risk was not statistically significant. The NPLs \& cost to income ratio had a negative effect on financial performance while total revenue $\&$ loan recovered had a positive influence on financial performance.

Wangai , Bosire and Gathogo (2012) investigated the effect of non-performing loans on financial performance of microfinance banks (MFBs) in Kenya. The research was carried out in MFBs in Nakuru town, Kenya. The results showed that, credit risk had significant effect on financial performance of Micro finance Banks in Nakuru town.

Awoyemi (2014) also analyzed the effect of Credit Risk Management on the performance of Commercial Banks in Nigeria. In the regression model, ROE and ROA were used as indicators of performance while NPLs and Capital Adequacy Ratio (CAR) were used as credit risk management proxies. The study collected data from annual reports of seven commercial banks for seven years beginning 2005 to 2011. From panel regression model, it was established that credit risk management practices have a statistically significant effect on the profits of commercial banks operating in Nigeria.

Muasya (2009) carried a comparative study to find out extent to which commercial banking institutions in Kenya and Europe were affected by problem of NPLs during the global financial crisis period 2008/2009. The study results showed that Kenyan banks made less losses as 


\section{International Journal of Social Science and Economic Research}

ISSN: $2455-8834$

Volume: 05, Issue: 05 "May 2020"

compared to banks in US and Europe in same period due to the negative effect of NonPerforming Loans.

Kargi (2011) examined the effect of credit risk on the financial performance of banks in Nigeria. The study employed financial ratios as proxies for performance of the bank. Data on credit risk was extracted from the financial reports of sampled banks covering five years beginning from 2004 to 2008. The data was analyzed using the descriptive and inferential statistics that is pare wise correlation and regression techniques analysis. The results revealed that credit risk management had a statistically significant effect on the financial performance, measured by profits, in banks in Nigeria. The study held those banks' profits is negatively affected by volume of loans and advances, NPLs and deposits hence exposing banks to great liquidity risk and financial distress.

Epure and Lafuente (2012) studied bank financial performance in banking industry in the presence of risk in Costa-Rica during the period 1998 to 2007. The finding revealed that improvement in performance followed changes in regulations and that risk explains differences in banks. NPLs were found to negatively affect efficiency and ROA while the capital adequacy ratio had a significant and positive effect on the net interest cover margin.

Kithinji (2010) examined the impact of credit risk management practices on the profits of commercial banking institutions operating in Kenya. Data on the amount of customer credit advanced, level of NPLs and profits were collected for five years (2004 - 2008). The results showed that that the big chunk of the profits of commercial banks are not affected by total customer credit and NPLs suggesting that their exist other variables apart from total customer credit and NPLs loans that impact on profits.

Chen and Pan (2012) assessed the credit risk efficiency of 34 commercial banks in Taiwanese for a period of four years (2005-2008). Chen and Pan used financial ratio as proxy for credit risk. Data was analyzed using DEA. The parameters of credit risk were credit risk allocative efficiency, credit risk cost efficiency and credit risk technical efficiency. The findings revealed that only one bank was efficient in all types of efficiencies over the study period evaluated.

Felix and Claudine (2008) assessed the association between banks' performance and credit risk management practices. Findings showed that that ROA and ROE, both measuring profitability of financial institutions, were negatively related to the ratio of NPLs to total loan of financial institutions hence leading to a decline in profitability.

Ahmad and Ariff (2007) did comparative study also analyzed the key determinants of credit risk of commercial banks in emerging and developed economy banking systems. The results revealed that regulation is an important determinant for banking systems that offer many products and ; 
International Journal of Social Science and Economic Research

ISSN: $2455-8834$

Volume: 05, Issue: 05 "May 2020"

quality of management was critical in the cases of loan-dominant banks in emerging economies. An increase in loan loss provision is also considered to be a significant factor affecting credit risk. Al-Khouri (2011) assesses the effect of bank's specific risks \& the overall banking environment on the financial performance of 43 commercial banks operating in six of the Gulf Cooperation Council (GCC) countries over the period between 1998 and 2008. The study employed fixed effect regression model for analysis. The findings revealed that credit risk, capital risk and liquidity risk are the key banks specific risks that affect bank performance (ROA) while only Liquidity risk affects profitability when measured by ROE.

Ben-Naceur and Omran (2008) examined the influence of financial institutional development, bank regulations and concentration on commercial banks' margin and profitability in the Middle East and North Africa countries (MENA) from 1989-2005.The study revealed that capitalization of the bank and credit risk had a significant and positive impact on banks' cost efficiency, net interest margin and profitability. Ahmed, Takeda and

\section{SECTION THREE}

\section{METHODOLOGY}

\subsection{Research Design}

The study adopt an ex-post facto research design because the data for the study are secondary data that already exist in the archive of well acclaimed financial publication such as the Central Bank of Nigeria.

\subsection{Nature and Sources of Data}

The study used secondary data that was sourced from financial publications such as the Central Bank of Nigeria, Statistical Bulletin and CBN Annual Reports and Accounts, Nigeria bureaus of Statistics (NBS) for the period under review. The variables which the researcher used include; return on asset (ROA) which is the dependent variable and credit to private sector, liquidity ratio, nonperforming loan and loan and advances are independent variables.

\subsection{Model Specification}

The model used for the study was the adaptation and modifications from the work of Agu and basil (2012) examined risk management on commercial banks in Nigeria.

The model was adapted and modified.

The model is stated thus: 
$\mathrm{ROA}=\mathrm{f}(\mathrm{CPS}, \mathrm{LTR}, \mathrm{NPL}, \mathrm{LAD})$--- -- -- --- -- -- -- -- - - - - -- - 1

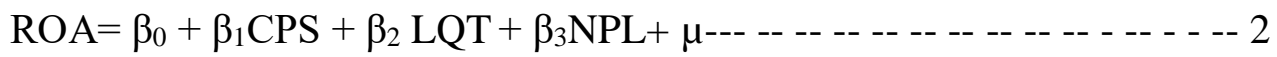

Where:

$\mathrm{ROC}=$ Return on Asset

LQTR= Liquidity Ratio

$\mathrm{NPL}=$ Nonperforming loan

$\mathrm{LA}=$ Loan and Advances

$\beta_{0}$ and $\mu$ are the constant and error term respectively while $\beta_{1}, \beta_{2}$, and $\beta_{3}$, are the coefficient of credit to private sector, liquidity ratio, nonperforming loan and loan and advances in return on asset

\subsection{Method of Analyses}

The data was analyzed with econometric techniques involving the unit root and ordinary least square (OLS).

\section{SECTION FOUR}

\section{DATA PRESENTATION AND ANALYSIS}

\subsection{Unit Root Test}

The unit root test is conducted using the Augmented Dickey Fuller (ADF) test proposed by Dickey and Fuller (1979). The result of ADF statistics is presented below.

\section{Table 4.1: Augmented Dickey Fuller Test}

\begin{tabular}{crcc}
\hline Variables & ADF Statistic & Order Of Integration & Level Of Significance \\
\hline ROA & -6.190751 & $1(1)$ & $5 \%$ \\
CPS & -5.494642 & $1(1)$ & $5 \%$ \\
LTR & -8.023468 & $1(1)$ & $5 \%$ \\
NPL & -4.554952 & $1(1)$ & $5 \%$ \\
LA & -11.66793 & $1(0)$ & $5 \%$ \\
\hline
\end{tabular}

Source: Authors Computation from E-View Version 8.0 
The result confirmed that loan and advances attained stationary at levels. Return on asset, credit to private sector, nonperforming loan and loan and advances were stationary after first difference. All the variables are significant at $5 \%$ level of significance.

Table 4.2: Ordinary Least Square Regressions

\begin{tabular}{lccll}
\hline Variable & Coefficient & Std. Error & \multicolumn{1}{c}{ t-Statistic } & Prob. \\
\hline C & 15.73210 & 5.435635 & 2.543973 & 0.0003 \\
CPS & 1.668951 & 0.991508 & 2.683245 & 0.0001 \\
LTR & 2.145270 & 0.695746 & 2.283798 & 0.0004 \\
NPL & -0.537317 & -0.785673 & -1.274907 & 0.6573 \\
LA & 3.53502 & 0.563352 & 2.325723 & 0.0021 \\
\hline R-squared & 0.701033 & Mean dependent var & 6.897917 \\
Adjusted R-squared & 0.682550 & S.D. dependent var & 1.094669 \\
S.E. of regression & 0.601022 & Akaike info criterion & 2.096940 \\
Sum squared resid & 4.334733 & Schwarz criterion & 2.444891 \\
Log likelihood & -12.92093 & F-statistic & 7.951898 \\
Durbin-Watson stat & 2.16708 & Prob(F-statistic) & 0.001265 \\
\hline
\end{tabular}

Computed by the Authors with E-View Software

From the above regression coefficients, we can express the model as follows:

ROA=15.73210, CPS $=1.668951$, LTR $2.145270+\mathrm{NPL}-0.537317+\mathrm{LA} 3.53502+\mathrm{u}$

From the results of the OLS, it is obvious that the constant parameter (Bo) is positive at +15.73210 . This means that if all the independent variables are held constant, ROA as a dependent variable will grow by 15.73210 units in annual-wide basis.

Credit to Private Sector: For credit to private sector the coefficient of (CPS) is positive at 1.668951 with the probability value of 0.0001 which means that credit to private sector have positive and significant effect in return on asset (ROA), a unit increase in credit to private sector will cause return on asset (ROA) to increase by 1.668951 units.

Liquidity Ratio: The coefficient of liquidity ratio (LQTR) is positive at 2.145270 with the probability value of 0.0004 which means that liquidity ratio (LQTR) has positive and significant 
effect in the return on asset (ROA). A unit increase in liquidity ratio (LQTR) will cause return on asset (ROA) to increase by 2.145270 units.

Nonperforming Loan: The coefficient of nonperforming loan (NPL) is negative at 0.537317 with probability value of 0.6573 which means that nonperforming loan (NPL) has negative and insignificant effect on the return on asset (ROA). A unit increase in nonperforming loan (NPL) will cause return on asset (ROA) to decrease by 0.537317 units.

Loan and Advances: For loan and advances the coefficient of (LA) is positive at 3.53502 with the probability value of 0.0021 which means that loan and advances have positive and significant effect in return on asset (ROA), a unit increase in loan and advances will cause return on asset (ROA) to increase by 3.53502 units.

Above all, the Adjusted R-squared is 0.682550 . This means that $70 \%$ of total variation in commercial return on asset can be explained by the variables, namely CPS, LTR, NPL and LA while the remaining $30 \%$ is due to other variables outside the model. The Durbin-Watson statistics at (2.16708) is within the critical threshold; this means the model is free from autocorrelation.

\subsection{Test of Hypotheses}

To test the hypotheses, the statistical significance of the individual parameters was used to test the hypotheses. These test were conducted at $5 \%$ level of significance

\section{Test of Hypothesis One}

\section{Stage One}

\section{Restatement of hypothesis in null and alternate form:}

Ho1: Credit to private sector has no significant effect on return on asset in Nigeria

Hi: Credit to private sector has significant effect on return on asset in Nigeria

\section{Stage Two}

\section{Analysis of the regression results}


Table 5: OLS on Risk Management, Risk Concentration on Performance of commercial Banks in Nigeria

\begin{tabular}{|c|c|c|c|c|}
\hline Variable & Coefficient & t-Statistic & Probability & Conclusion \\
\hline Constant & 15.73210 & 2.543973 & 0.0003 & $\begin{array}{c}\text { Statistically } \\
\text { Positive and } \\
\text { Significance }\end{array}$ \\
\hline CPS & 1.668951 & 2.683245 & 0.0001 & $\begin{array}{c}\text { Statistically } \\
\text { Positive and } \\
\text { Significance }\end{array}$ \\
\hline LTR & 2.145270 & 2.283798 & 0.0004 & $\begin{array}{c}\text { Statistically } \\
\text { Positive and } \\
\text { Significance }\end{array}$ \\
\hline NPL & -0.537317 & -1.274907 & 0.6573 & \begin{tabular}{c} 
Statistically \\
Negative and \\
Insignificance \\
\hline LA
\end{tabular} \\
\hline \multirow{2}{*}{1.342700} & 2.325723 & 0.0021 & $\begin{array}{c}\text { Statistically } \\
\text { Positive and } \\
\text { Significance }\end{array}$ \\
\hline
\end{tabular}

Source: Computed from E- view 9.0

\section{Stage Three: Decision}

From table 5 above, since the probability value is less than $5 \%(0.0001<0.05)$ with coefficient value of 1.668951 and t-Statistic of 2.683245 , the studies therefore reject the null hypothesis and accept the alternative hypothesis: these imply that credit to private sector has positive and significant effect on return asset in Nigeria

\section{Hypothesis Two}

\section{Stage One}




\section{Restatement of Hypothesis in Null and Alternate Form:}

$\mathrm{Ho}_{2}$ : Liquidity ratio has no significant effect on return on asset in Nigeria

Hi: Liquidity ratio has significant effect on return on asset in Nigeria.

\section{Stage Two}

Analysis of the regression results,

Table 6: OLS on Risk Management, Risk Concentration on Performance of commercial Banks in Nigeria

\begin{tabular}{|c|c|c|c|c|}
\hline Variable & Coefficient & t-Statistic & Probability & Conclusion \\
\hline Constant & 15.73210 & 2.543973 & 0.0003 & $\begin{array}{c}\text { Statistically } \\
\text { Positive and } \\
\text { Significance }\end{array}$ \\
\hline CPS & 1.668951 & 2.683245 & 0.0001 & $\begin{array}{c}\text { Statistically } \\
\text { Positive and } \\
\text { Significance }\end{array}$ \\
\hline LTR & 2.145270 & 2.283798 & 0.0004 & $\begin{array}{c}\text { Statistically } \\
\text { Positive and } \\
\text { Significance }\end{array}$ \\
\hline NPL & -0.537317 & -1.274907 & 0.6573 & $\begin{array}{c}\text { Statistically } \\
\text { Negative and } \\
\text { Insignificance }\end{array}$ \\
\hline LA & 1.342700 & 2.325723 & 0.0021 & $\begin{array}{c}\text { Statistically } \\
\text { Positive and } \\
\text { Significance }\end{array}$ \\
\hline
\end{tabular}

Source: Computed from E- view 9.0

\section{Stage three: Decision}

Table 6 above reveals that the probability value is less than $5 \%(0.0004<0.05)$ with coefficient value of 2.145270 and t-Statistic of 2.283798 , the study therefore accept the null hypothesis and reject the alternative hypothesis and summit that liquidity ratio has significant effect on return on asset in Nigeria

\section{Hypothesis Three}

\section{Stage One}




\section{Restatement of Hypothesis in Null and Alternate Form}

$\mathrm{Ho}_{3}$. Nonperforming has no significant effect on return on asset in Nigeria

Hi. Nonperforming has significant effect on return on asset in Nigeria

\section{Stage Two}

Analysis of the Regression Results

Table 7: OLS on Risk Management, Risk Concentration on Performance of commercial Banks in Nigeria

\begin{tabular}{|c|c|c|c|c|}
\hline Variable & Coefficient & t-Statistic & Probability & Conclusion \\
\hline Constant & 15.73210 & 2.543973 & 0.0003 & $\begin{array}{c}\text { Statistically } \\
\text { Positive and } \\
\text { Significance }\end{array}$ \\
\hline CPS & 1.668951 & 2.683245 & 0.0001 & $\begin{array}{c}\text { Statistically } \\
\text { Positive and } \\
\text { Significance }\end{array}$ \\
\hline LTR & 2.145270 & 2.283798 & 0.0004 & $\begin{array}{c}\text { Statistically } \\
\text { Positive and } \\
\text { Significance }\end{array}$ \\
\hline NPL & -0.537317 & -1.274907 & 0.6573 & $\begin{array}{c}\text { Statistically } \\
\text { Negative and } \\
\text { Insignificance }\end{array}$ \\
\hline LA & 1.342700 & 2.325723 & 0.0021 & $\begin{array}{c}\text { Statistically } \\
\text { Positive and } \\
\text { Significance }\end{array}$ \\
\hline
\end{tabular}

Source: Computed from E- view 9.0

\section{Stage three: Decision}

From table 7 above, since the probability value is more than 5\% (0.6573>0.05) with coefficient value of -0.537317 and $t-S t a t i s t i c$ of -1.274907 the studies therefore accept the null hypothesis and reject the alternative hypothesis: which means that government borrowing has negative and insignificant effect on gross domestic product in Nigeria

\section{Hypothesis Four}

\section{Stage One}




\section{Restatement of Hypothesis in Null and Alternate Form:}

Ho4. Loan and advances has no significant effect on return on asset in Nigeria

Hi. Loan and advances has significant effect on return on asset in Nigeria

\section{Stage Two}

Analysis of the Regression Results,

Table 8: OLS on Risk Management, Risk Concentration on Performance of commercial Banks in Nigeria

\begin{tabular}{|c|c|c|c|c|}
\hline Variable & Coefficient & t-Statistic & Probability & Conclusion \\
\hline Constant & 15.73210 & 2.543973 & 0.0003 & $\begin{array}{c}\text { Statistically } \\
\text { Positive and } \\
\text { Significance }\end{array}$ \\
\hline CPS & 1.668951 & 2.683245 & 0.0001 & $\begin{array}{c}\text { Statistically } \\
\text { Positive and } \\
\text { Significance }\end{array}$ \\
\hline LTR & 2.145270 & 2.283798 & 0.0004 & $\begin{array}{c}\text { Statistically } \\
\text { Positive and } \\
\text { Significance }\end{array}$ \\
\hline NPL & -0.537317 & -1.274907 & 0.6573 & $\begin{array}{c}\text { Statistically } \\
\text { Negative and } \\
\text { Insignificance }\end{array}$ \\
\hline LA & 1.342700 & 2.325723 & 0.0021 & $\begin{array}{c}\text { Statistically } \\
\text { Positive and } \\
\text { Significance }\end{array}$ \\
\hline
\end{tabular}

Source: Computed from E- view 9.0

\section{Stage Three: Decision}

From table 8 above, since the probability value is less than $5 \%(0.0021<0.05)$ with coefficient value of 1.342700 and t-Statistic of 2.325723, the studies therefore reject the null hypothesis and accept the alternative hypothesis: which means that loan and advances has positive and significant effect on return on asset in Nigeria

\subsection{Discussion of Finding}


The result of the ordinary least square (OLS) indicates that credit to private sector has positive and significant effect in return on asset (ROA), the results of our findings are consistent with the work of Agbaeze and Onwuka (2014)) in terms of credit to private sector, it was discovered that credit to private sector has positive and significant effect in return on asset (ROA)

Liquidity Ratio: The result indicates that liquidity ratio has positive and significant effect in return on asset (ROA)

The result of our findings are consistent with the work of Anthony, Onyinye and Peter (2015), they posit that liquidity ratio has positive and significant effect in return on asset (ROA)

Akpan (2014), which confirm that liquidity ratio had a positive relationship with return on asset (ROA) and that a high level of liquidity ratio will improve the performance of commercial banks in Nigeria

Nonperforming loan (NPL): the result indicates that, nonperforming loan has negative and insignificant effect in return on asset (ROA)

The result of our findings are consistent with the work of Gecizi (2011) in terms of nonperforming loan, it was discovered that nonperforming loan has negative and insignificant effect in return on asset (ROA)

Loan and Advances: the result of the study indicate that loan and advances have positive and significant effect in return on asset (ROA),

The result of our findings is consistent with the work of Omotola \& Safoura (2012) in terms of loan and advances, it was discovered that loan and advances has positive and significant effect in return on asset (ROA)

\section{SECTION FIVE}

\section{SUMMARY, CONCLUSION AND RECOMMENDATION}

\subsection{Summary of the Study}

In line with the research objective and hypothesis, the result of the study indicates that credit to private sector, liquidity ratio and loan and advances has positive and significant effect in return on asset (ROA) while nonperforming loan has negative and insignificant effect in return on asset (ROA)

Above all, the Adjusted R-squared is 0.682550 . This means that $70 \%$ of total variation in commercial return on asset can be explained by the variables, namely CPS, LTR, NPL and LA 
International Journal of Social Science and Economic Research

ISSN: $2455-8834$

Volume: 05, Issue: 05 "May 2020"

while the remaining $30 \%$ is due to other variables outside the model. The Durbin-Watson statistics at (2.16708) is within the critical threshold; this means the model is free from autocorrelation

\subsection{Conclusion}

The result of the study indicates that credit to private sector, liquidity ratio and loan and advances has positive and significant effect in return on asset (ROA) while nonperforming loan has negative and insignificant effect in return on asset (ROA)

The study thus concludes that risk management has positive effect on the performance of commercial banks in Nigeria and support Moody`s KMV portfolio manager model which is a credit monitor model that helps to solve the lending problems of banks and further look at the repayment incentive problem (Gilbert, 2004).

\subsection{Recommendation of the Study}

1. Banks Management should establish sound lending policies, adequate credit administration procedure and an effective and efficient machinery to monitor lending function with established guidelines, reduction of interest rates on lending. The character and financial statement of the borrower must be properly studied. The Central Bank of Nigeria should re-introduce interest rate regulation on banks.

2. Banks should publish the names of bad and doubtful debtors (by compilation of bad debtors' black book in banks).

3. Financial institutions should all together, set up credit bureau system which is a form of data bank where every bank will submit the names of its defaulting customers for references by others. This will equally frustrate multiple borrowing from banks for the same purpose by the dubious customers.

\section{REFERENCES}

Aremu, O., Suberu, J., and Oke, J., (2010). Effective Credit Processing and Administration as a Panacea for Non-performing Assets in the Nigerian Banking System. Kre Journal of Economics $1(1), 53-56$

Calandro J. and Lane S. (2006), Insights from the balanced scorecard - An introduction to the enterprise risk scorecard, Measuring Business Excellence, Vol. 10 No. 3, pp. 31-40.

Casu, B., Molyneux, P. And Girardone, C.(2006). Introduction to Banking, Prentice Hall/Financial Times, London. 
International Journal of Social Science and Economic Research

ISSN: 2455-8834

Volume: 05, Issue: 05 "May 2020"

Halkos, G. and Salamouris, D. (2004). Efficiency measurement of the Greek commercial banks with the use of financial ratios: a data envelope analysis approach. Management Accounting Research 15(2), pp 201- 224.

Kolapo T. F., Ayeni R. K, \& Oke M. O.(2012). Credit Risk and Commercial Banks' Performance in Nigeria: A Panel Model Approach. Australian Journal of Business and Management Research. Vol. 2 No. 02 pp 31-38

Lacewell, S., K (2003). Do Efficient Institutions Score Well Using Ratio Analysis? An Examination of Commercial Banks in the 1990s. Journal of Commercial Banking and Finance 2, pp 17-33.

Marsh, I.W. (2008).The Effect of Lenders' Credit Risk Transfer Activities on Borrowing Firms' Equity Returns, Cass Business School, London and Bank of Finland.

Michalak, T. \& Uhde, A. (2009).Credit Risk Securitization and Banking Stability: Evidence from the Micro-Level for Europe", Draft, University of Bochum, Bochum.

Study on the Karachi Stock Exchange of Pakistan". International Journal of Business and Social Science, 2 (6), 27 Omotola A., Roya A. \& Safoura N. (2012).

Analysing Risk Management in Banks: Evidence of Bank Efficiency and Macroeconomic Impact. Journal of Social Sciences. Vol.3. no. 10

Sadaqat, M. S., Akhtar, M. F., \& Ali, K.(2011). "An Analysis on the Performance of IPO A 5285.

Samad, A. (2004). Bahrain Commercial Bank's Performance during 1994-2001. Credit and Financial Management Review 10(1) pp 33-40.

Seiford, L., M and Zhu, J(1999). Profitability and Marketability of the Top 55 U.S. Commercial Banks Management Science 45 (9), pp 1270-1288.

Tarawneh, M. (2006). A Comparison of Financial Performance in the Banking Sector: Some Evidence from Omani Commercial Banks". International Research Journal of Finance and Economics 3, pp 103-112.

Thygerson, K., J. (1995). Management of financial Institutions, HarperCollins

Van der Stede, W. (2009), Enterprise Governance, Financial Management, February, pp. 38-40. 
Webb, R.M. (2003). Levels of efficiency in UK retail banks: a DEA window analysis. Interational Journal of the Economics of Business Vol 10 (3), pp 305-322.

Woods, M. Kajüter, P. and Linsley, P. (2008), International risk management, CIMA publishing, London.

Yeh, Q., J. (1996). The Application of Data Envelopment Analysis in Conjunction with Financial Ratios for Bank Performance Evaluation. Journal of the Operational Research Society 47, pp 980-988. 